\title{
EVALUATION OF IN VITRO CYTOTOXIC EFFECT OF VIOLACEIN PRODUCED BY NOVEL ISOLATE CHROMOBACTERIUM VACCINII CV5 AGAINST THE CERVICAL AND LUNG CANCER CELL
}

\author{
VISHNU T SANTHOSH*, PALANISWAMY MUTHUSAMY
}

Department of Microbiology, School of Life Sciences, Karpagam Academy of Higher Education, Karpagam University, Coimbatore - 641 021, Tamil Nadu, India. Email: tsvishnu1988@gmail.com

Received: 05 June 2017, Revised and Accepted: 28 June 2017

\begin{abstract}
Objectives: This study investigates the in vitro anticancer activity of the violacein extracted from the Chromobacterium vaccinii CV5.

Methods: Natural colorants or dyes derived from flora to fauna are believed to be safe because of nontoxic, noncarcinogenic, and biodegradable in nature. There are a number of natural pigments, but only a few are available in sufficient quantities for industrial production. The cytotoxicity activity of pigment was assessed against the cervical (HeLa) and lung cancer (A549) cell lines using the MTT assay and there by potential cytotoxic activity exhibited by the pigment was identified.
\end{abstract}

Results: The result of the pigment shows potent anticancer activity on the two cancer cell lines tested in a concentration dependent manner. The potent anticancer activity was observed with the pigment with $\mathrm{IC}_{50}$ values of $26 \mu \mathrm{g} / \mathrm{mL}$ on HeLa and $31 \mu \mathrm{g} / \mathrm{mL}$ on A549 cells, respectively.

Conclusion: The study is pioneering report for determining the better in vitro anticancer activity of violacein from the novel isolate $C$. vaccinii CV5.

Keywords: Anticancer, Cytotoxicity, Chromobacterium, MTT assay, Pigment, Violacein.

(C) 2017 The Authors. Published by Innovare Academic Sciences Pvt Ltd. This is an open access article under the CC BY license (http://creativecommons. org/licenses/by/4. 0/) DOI: http://dx.doi.org/10.22159/ajpcr.2017.v10i10.20456

\section{INTRODUCTION}

Violacein is characterized as 2-dihydro-5-(5-hydroxy-1H-indol-3-yl)-2oxo-3H-pyrrol-3-ilydene)-1,3-dihydro-2H-indol-2-one, formed by the condensation of two modified L-tryptophan molecules [1]. Violacein is produced by several bacterial species thriving in a range of habitats such as terrestrial, marine, fresh water, and glacier environments. Some of the known violacein producing organisms include Chromobacterium violaceum [2], Collimonas sp. [3], Duganella sp. [4], Janthinobacterium lividum [5,6], and Pseudoalteromonas sp. [7,8].

Violacein has also gained increasing importance for its potential medical and industrial applications. The biological activities of this compound include antioxidant, leishmanicidal, trypanocidal, antifungal, antiviral, antibacterial and antiprotozoal activity, as well as antitumoral and apoptosis inducing activities in the mammalian cancer cells.

Cancer is one of the most serious threats to human health in the world and chemotherapy is still the standard treatment method. Most of the anticancer drugs currently used in chemotherapy are cytotoxic to normal cells and cause immunotoxicity which affects not only tumor development, but also aggravates patient's recovery. The discovery and identification of new antitumor drug with low side effects on the immune system have become an essential goal in many studies of immunopharmacology [9-11].

To resolve side effects of anticancer agents, development of cancer chemopreventive agents and improvement of cancer treatment are very important. Accordingly, screening of natural products as potential anticancer agents, in the form of functional foods or nutraceuticals has become an important undertaking [12]. The rising interest in the pharmacological properties of microbial pigments led us to investigate in vitro cytotoxicity of the violacein, violet color pigment, extracted and purified from the novel isolate Chromobacterium vaccinii CV5.

\section{METHODS}

\section{Microorganisms}

The C. vaccinii CV5 isolated from the well water identified by morphologically and genetically was used in this study [13].

\section{Pigment production and purification}

The production profile of crude violacein was obtained using a $500 \mathrm{~mL}$ flask containing $200 \mathrm{~mL}$ of nutrient broth. Fermentations were carried out at $37^{\circ} \mathrm{C}$ for $72 \mathrm{hrs}$ with an inoculum size of $8 \%(\mathrm{v} / \mathrm{v}) 24 \mathrm{hrs}$ old culture (OD 660 approximately 1). After $72 \mathrm{hrs}$ of incubation period broth was taken for pigment extraction. The partially purified compound was used for the further study.

\section{In vitro cell line study by MTT assay}

The cell lines, HeLa (cervical cancer cell) and A549 (lung cancer cell) used in this study were obtained from the National Centre for Cell Sciences, Pune. The cells were maintained in RPMI-1640 supplemented with $10 \%$ fetal bovine serum, penicillin $(100 \mathrm{U} / \mathrm{mL})$, and streptomycin $(100 \mu \mathrm{g} / \mathrm{mL})$ in a humidified atmosphere of $50 \mu \mathrm{g} / \mathrm{mL} \mathrm{CO}_{2}$ at $37^{\circ} \mathrm{C}$.

The cytotoxicity of samples on the cells was determined by the MTT assay [14]. Cells $\left(1 \times 10^{5} /\right.$ well $)$ were plated in $100 \mu \mathrm{L}$ of medium/well in 96-well plates (Costar Corning, Rochester, NY). After $48 \mathrm{hrs}$ of incubation, the cell reaches the confluence. Then, the cells were incubated in the presence of various concentrations of the samples in $0.1 \%$ dimethyl sulfoxide for $48 \mathrm{hrs}$ at $37^{\circ} \mathrm{C}$. After removal of the sample solution and washing with phosphate-buffered saline ( $\mathrm{pH} 7.4)$, $20 \mu \mathrm{L} /$ well $(5 \mathrm{mg} / \mathrm{mL})$ of $0.5 \% 3$-(4, 5-dimethyl-2-thiazolyl)-2,5diphenyl-tetrazolium bromide cells (MTT) phosphate-buffered saline solution was added. After $4 \mathrm{hrs}$ incubation, $0.04 \mathrm{M} \mathrm{HCl}$ /isopropanol was added. Viable cells were determined by the absorbance at $570 \mathrm{~nm}$ with reference at $655 \mathrm{~nm}$. Measurements were performed in 3 times, and the concentration required for a $50 \%$ inhibition of viability $\left(\mathrm{IC}_{50}\right)$ was determined graphically. The absorbance at $570 \mathrm{~nm}$ was measured with a microplate reader (Bio-Rad, Richmond, CA), using wells without 
sample containing cells as blanks. All the experiments were performed in triplicate. The percentage of cell inhibition was determined using the formula:

$\%$ Cell inhibition=100-abs (drug)/abs (control) $\times 100$

\section{Statistical analysis}

All the experiments were conducted with triplicates, and their mean values were represented. Statistical analysis was performed by the oneway ANOVA using SPSS version 10. All the results were expressed as the mean \pm standard deviation.

\section{RESULTS AND DISCUSSION}

In this study, violacein pigment was extracted from $C$. vaccinii CV5, and the partially purified pigment was analyzed for its in vitro anticancer activity using cervical (HeLa) and lung cancer cells (A549). It was found that the incubation of tumor cells with the pigment significantly reduced the viability of these cells and the dead cells were significantly increased with high pigment concentration. To show the concentration dependent action of the pigment in cancer cells was treated with different $(6.25,12.5,25,50$ and $100 \mu \mathrm{g} / \mathrm{mL})$ concentration of the sample. After treatment for $48 \mathrm{hrs}$, the violacein from $C$. vaccinii CV5 decreased the proliferation of both cells significantly (Fig. 1).

The effect of violacein pigment on the growth of HeLa and A549 was investigated by the MTT assay (Fig. 2). The maximum percentage of inhibition value obtained against the HeLa was $72.02 \%$ at $100 \mu \mathrm{g} /$ $\mathrm{mL}$. The minimum percentage of $(10.36 \%)$ inhibition was observed at $6.25 \mu \mathrm{g} / \mathrm{mL}$. The $\mathrm{IC}_{50}$ value of violacein was found to be $26 \mu \mathrm{g} / \mathrm{mL}$. There was a significant association between the concentration of the sample and the inhibitory effect.

In this in vitro cytotoxicity assay, the violacein exhibits significant activity against A549 lung cancer cell line. The growth inhibitory effect of violacein against A549 human lung cancer cell line is shown in Fig. 3. The violacein reduces the A549 cell growth in a concentration dependent manner. Cell growth is decreased with the increasing concentration of pigment sample. From Fig. 1, it is showed that the pigment has good inhibition on A549 cell line proliferation with IC $_{50}$ of $31 \mu \mathrm{g} / \mathrm{mL}$.

Recent studies reveal that so many natural byproducts including microorganism and its byproducts could acts as a tumor suppressor or as a chemotherapeutic agent. Kodach et al. [15] show that the violacein $\left(\mathrm{IC}_{50} 1-2 \mu \mathrm{M}\right)$ is a promising chemotherapeutic agent that acts by blocking AKT activation and inducing apoptosis thus increasing the chemosensitivity of colon cancer cells to 5-fluorouracil treatment. Ferreira et al. [16] in their study investigate the effect of violacein in leukemia (HL60) cell. They demonstrated that violacein from Chromobacterium violaceum represents the first member of a novel class of cytotoxic drugs mediating apoptosis of HL60 cells by way of the specific activation of tumor necrosis factor receptor 1 and caspases.

Anticancer studies of violacein have shown efficiency in a number of cell lines of both neoplastic and hematological malignant origins. Melo et al. [17] find that the violacein ( $\mathrm{IC}_{50} 5-12 \mu \mathrm{M}$ ) is highly cytotoxic to V79 fibroblasts. Saraiva et al. [18] find that uveal melanoma cell lines, 92.1 and OCM-1, are found to be sensitive to violacein (GI50 $\sim 1.69-2.21 \mu \mathrm{M}$ ). These results demonstrate that the violacein induces apoptosis in cancer cells. Apoptosis is necessary for the conservation of tissues homeostasis and important for defense against the diseases and cancers $[19,20]$.

\section{CONCLUSION}

In this study, it shows that the violacein has an inhibitory effect on both HeLa and A549 cell. Chemotherapy and radiotherapy used currently have partially fails to give significant therapeutic results because of

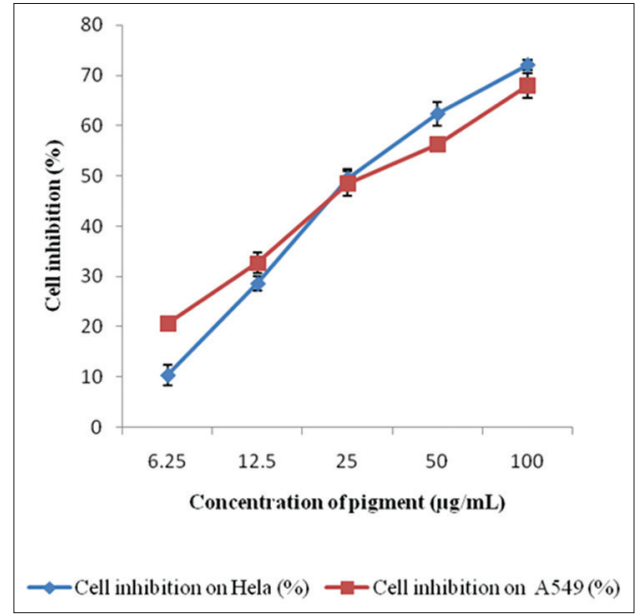

Fig. 1: The cytotoxic effect of violacein on cancer cell lines

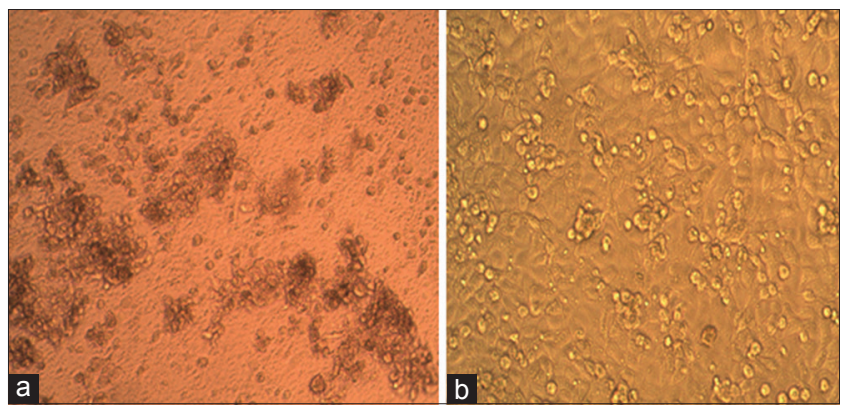

Fig. 2: (a and b) Cell inhibitions by violacein and control HeLa cell

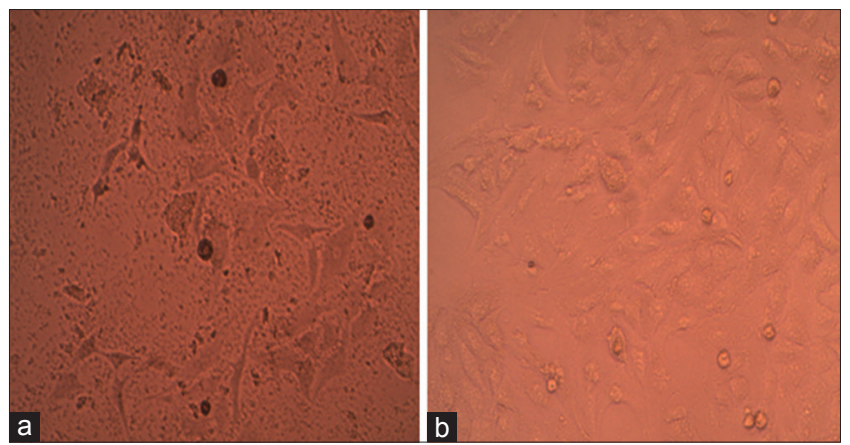

Fig. 3: ( $a$ and b) Cell inhibition by violacein and control A549 cell

nonspecific pointing of drugs. This has led to many complications, such as toxicities and relapse in cancer patients. The potentiality of natural compounds in inducing encountered cell death (apoptosis), a process of dysregulated in cancer cells, has been extensively studied in the recent studies. This study assesses the antiproliferative in vitro activity of violacein against HeLa and A549 human cancer cell lines. The current study is pioneering report for determining the better in vitro anticancer activity of violacein from the novel isolate $C$. vaccinii CV5.

\section{REFERENCES}

1. Durán N, Menck CF. Chromobacterium violaceum: A review of pharmacological and industiral perspectives. Crit Rev Microbiol 2001;27(3):201-22.

2. Hoshino T. Violacein and related tryptophan metabolites produced by Chromobacterium violaceum: Biosynthetic mechanism and pathway for construction of violacein core. Appl Microbiol Biotechnol 2011;91(6):1463-75.

3. Hakvåg S, Fjaervik E, Klinkenberg G, Borgos SE, Josefsen KD, Ellingsen TE, et al. Violacein-producing Collimonas sp. from the sea 
surface microlayer of costal waters in Trøndelag, Norway. Mar Drugs 2009;7(4):576-88

4. Aranda S, Montes-Borrego M, Landa BB. Purple-pigmented violaceinproducing Duganella spp. inhabit the rhizosphere of wild and cultivated olives in southern Spain. Microb Ecol 2011;62(2):446-59.

5. Pantanella F, Berlutti F, Passariello C, Sarli S, Morea C, Schippa S. Violacein and biofilm production in Janthinobacterium lividum. J Appl Microbiol 2007;102:992-9.

6. Lu Y, Wang L, Xue Y, Zhang C, Xing XH, Lou K, et al. Production of violet pigment by a newly isolated psychotropic bacterium from a glacier in Xinjiang, China. Biochem Eng J 2009;43:135-41.

7. Matz C, Webb JS, Schupp PJ, Phang SY, Penesyan A, Egan S, et al. Marine biofilm bacteria evade eukaryotic predation by targeted chemical defense. PLoS One 2008;3(4):e2744.

8. Yang LH, Xiong H, Lee OO, Qi SH, Qian PY. Effect of agitation on violacein production in Pseudoalteromonas luteoviolacea isolated from a marine sponge. Lett Appl Microbiol 2007;44(6):625-30.

9. $\mathrm{Xu} \mathrm{H}$, Yao L, Sung H, Wu L. Chemical composition and antitumor activity of different polysaccharides from the roots Actinidia eriantha. Carbohydr Polym 2009;78:316-22.

10. Ravin S, Gourav C, Anterpret C, Reena VS. Antioxidant and anticancer activity of methanolic extract from Stephania elegans. Int J Pharm Pharm Sci 2017;9(2):245-9.

11. Felisa $\mathrm{P}$, Nisha $\mathrm{K}$, Hyacinth $\mathrm{H}$, Linz BG. In vitro antioxidant and anticancer activity of Mimosa pudica Linn extract and L-mimosine on lymphoma daudi cells. Int J Pharm Pharm Sci 2015;12:100-4.

12. Kaefer CM, Milner JA. The role of herbs and spices in cancer prevention. J Nutr Biochem 2008;19(6):347-61.

13. Vishnu TS, Palaniswamy $M$. Isolation and identification of Chromobacterium sp from different ecosystems. Asian J Pharm Clin Res 2016;9(3):253-7.

14. Mosmann T. Rapid colorimetric assay for cellular growth and survival: Application to proliferation and cytotoxicity assays. J Immunol Methods 1983;65(1-2):55-63.

15. Kodach LL, Bos CL, Durán N, Peppelenbosch MP, Ferreira CV, Hardwick JC. Violacein synergistically increases 5-fluorouracil cytotoxicity, induces apoptosis and inhibits Akt-mediated signal transduction in human colorectal cancer cells. Carcinogenesis 2006;27(3):508-16.

16. Ferreira CV, Bos CL, Versteeg HH, Justo GZ, Durán N, Peppelenbosch MP. Molecular mechanism of violacein-mediated human leukemia cell death. Blood 2004;104(5):1459-64.

17. Melo PS, Justo GZ, de Azevedo MB, Durán N, Haun M. Violacein and its beta-cyclodextrin complexes induce apoptosis and differentiation in HL60 cells. Toxicology 2003;186(3):217-25.

18. Saraiva VS, Marshall JC, Cools-Lartigue J, Burnier MN Jr. Cytotoxic effects of violacein in human uveal melanoma cell lines. Melanoma Res 2004;14(5):421-4

19. Yao G, Yang L, Hu Y, Liang J, Liang J, Hou Y. Nonylphenol-induced thymocyte apoptosis involved caspase- 3 activation and mitochondrial depolarization. Mol Immunol 2006;43:915-26.

20. Walsh JG, Cullen SP, Sheridan C, Lüthi AU, Gerner C, Martin SJ. Executioner caspase-3 and caspase-7 are functionally distinct proteases. Proc Natl Acad Sci U S A 2008;105(35):12815-9. 